Provided for non-commercial research and education use. Not for reproduction, distribution or commercial use.

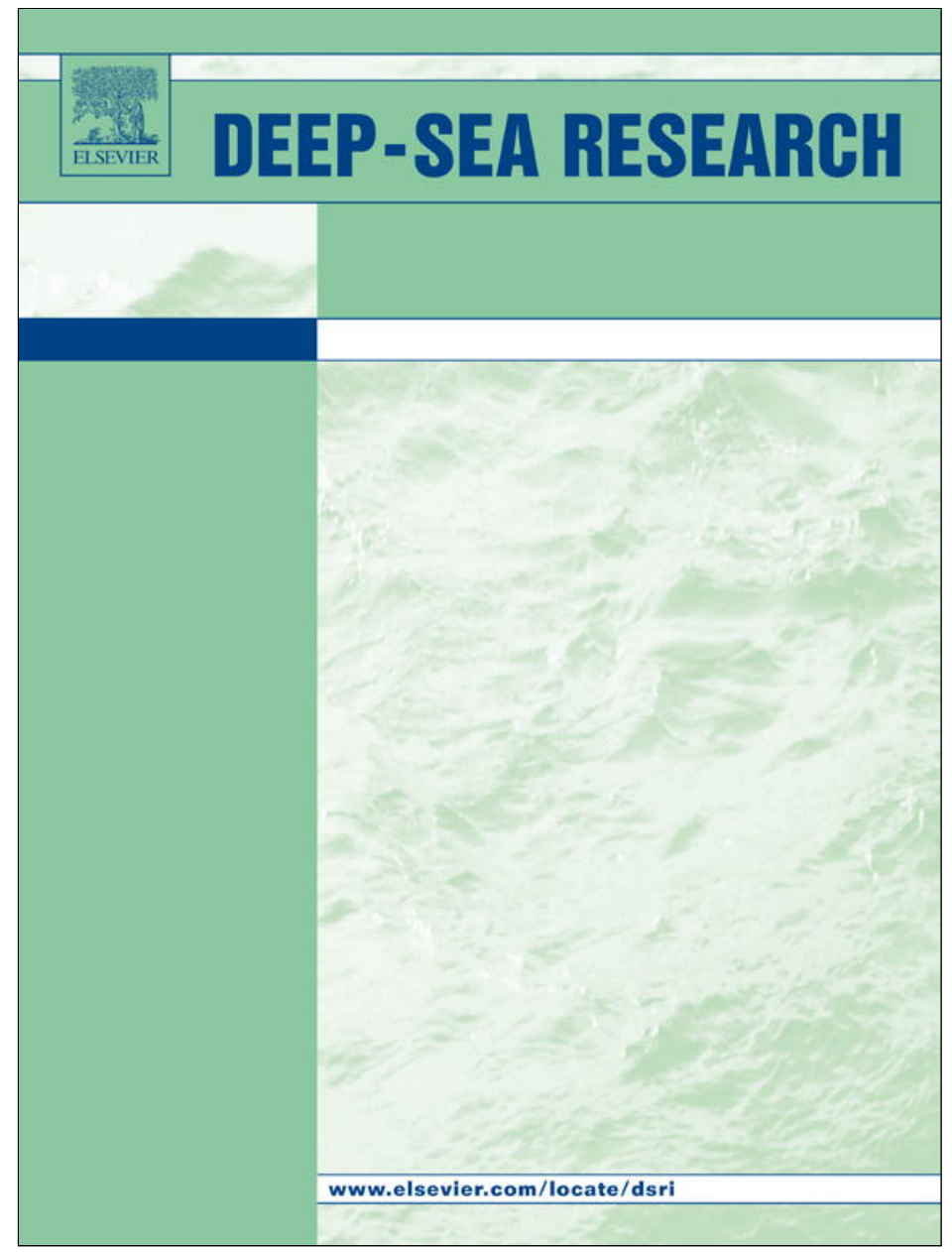

(This is a sample cover image for this issue. The actual cover is not yet available at this time.)

This article appeared in a journal published by Elsevier. The attached copy is furnished to the author for internal non-commercial research and education use, including for instruction at the authors institution and sharing with colleagues.

Other uses, including reproduction and distribution, or selling or licensing copies, or posting to personal, institutional or third party websites are prohibited.

In most cases authors are permitted to post their version of the article (e.g. in Word or Tex form) to their personal website or institutional repository. Authors requiring further information regarding Elsevier's archiving and manuscript policies are encouraged to visit:

http://www.elsevier.com/copyright 


\title{
Hydrographic variability of Denmark Strait Overflow Water near Cape Farewell with multi-decadal to weekly time scales
}

\author{
Hendrik M. van Aken*, M. Femke de Jong ${ }^{1}$ \\ NIOZ Royal Netherlands Institute for Sea Research, Den Burg, Texel, Netherlands
}

\section{A R T I C L E I N F O}

\section{Article history:}

Received 5 January 2012

Received in revised form

30 March 2012

Accepted 10 April 2012

Available online 20 April 2012

\section{Keywords:}

Hydrographic variation

Denmark strait

Overflow

Irminger Sea

\begin{abstract}
A B S T R A C T
Data in temperature and salinity from near-bottom layer of Denmark Strait Overflow Water in the Irminger Sea near $60^{\circ} \mathrm{N}$ are presented. These are hydrographic section data from data archives, literature, and CTD observations along the former WOCE AR7E line, as well as data from continuous measurements at two locations. For both salinity and temperature, hydrographic variability was present at all time scales that could be analysed, from multi-decadal to weekly. A mechanistic explanation for the primal cause of the hydrographic variability is still lacking. The direct cause of the observed variability has to be sought in variations of the properties of the source water types involved in the overflow across the sill in Denmark Strait, variations in the mutual ratios of these source water types, and in inhomogeneities in the DSOW layer. The strongest changes occurred at the longest time scales, as is often found for ultimately randomly forced geophysical time series. However, a significant annual cycle of the DSOW, not reported before, was observed at the foot of the East Greenland continental slope, likely a deterministic contribution to the hydrographic variability signal.
\end{abstract}

(c) 2012 Elsevier Ltd. All rights reserved.

\section{Introduction}

For a long time a steady-state ocean was assumed in oceanography (Neumann and Pierson, 1966; Tchernia, 1980). Even in the "World Ocean Circulation Experiment" (WOCE), the main emphasis of its hydrographic programme was to establish the "state of the world ocean" by combining single survey data from the field phase period 1990-1997. Repeat surveys were planned only for a minor part of the WOCE hydrographic lines, to determine the representativeness of the single survey data set. Thanks to such repeat surveys it has become clear that hydrographic variability is as much a characteristic of the ocean circulation as is the mean state. In the science plan of the following Climate Variability and Predictability Programme (CLIVAR), the study of variability of the ocean on seasonal to inter-annual time scales and its predictability became explicit scientific objectives (CLIVAR Scientific Steering Group, 1995). The coupled ocean/atmosphere system is much too complex to expect zero-energy elements at any scales. Even white noise in the atmospheric forcing of the ocean by the "weather" will result in hydrographic variability at finite time scales (Hasselmann, 1976). Such "red noise" fluctuations are the "natural variability" of the ocean (Wunsch, 1992). In this paper we study that natural

\footnotetext{
* Corresponding author. Tel.: +31222 369416; fax: +31222319674. E-mail address: aken@nioz.nl (H.M. van Aken).

${ }^{1}$ Present Address: Woods Hole Oceanographic Institution.
}

variability of Denmark Strait Overflow Water (DSOW) in the Irminger Sea. DSOW forms the largest dense water plume from the Nordic seas to feed the lower limb of the Atlantic meridional circulation (Våge et al., 2011).

The warm waters, entering the Norwegian Sea across the Iceland-Scotland Ridge are cooled in the Nordic Seas and Polar Ocean and return from there back into the North Atlantic Ocean at several locations over the Greenland-Scotland Ridge. The most important outflow probably takes place through Denmark Strait, the submarine passage between Greenland and Iceland (Fig. 1). This outflow consists of the relatively shallow East Greenland Current and the deeper overflow across the sill in this sea strait. The overflow, appropriately named Denmark Strait Overflow Water, imports the densest source water type for the formation of the water mass that occupies the cold branch of the Atlantic Meridional Overturning Circulation (AMOC), the North Atlantic Deep Water (NADW). According to Tanhua et al. (2005) deep water types of both the Nordic seas (low salinity component) and the Arctic Ocean (high salinity component) are important for the formation of DSOW. At approximately $60^{\circ} \mathrm{N}$ along the AR7E section, DSOW (Fig. 2) is observed over the East Greenland slope and over abyssal plain. It is bound to the east by the shallow Reykjanes Ridge. The core of the DSOW transport is found on the western side of the basin, over the East Greenland slope (Dickson and Brown, 1994). DSOW is characterised by low potential temperatures $\left(\sim 1-2.5^{\circ} \mathrm{C}\right)$ and by a relatively low salinity (34.86-34.90). DSOW is overlain by North East Atlantic Deep 


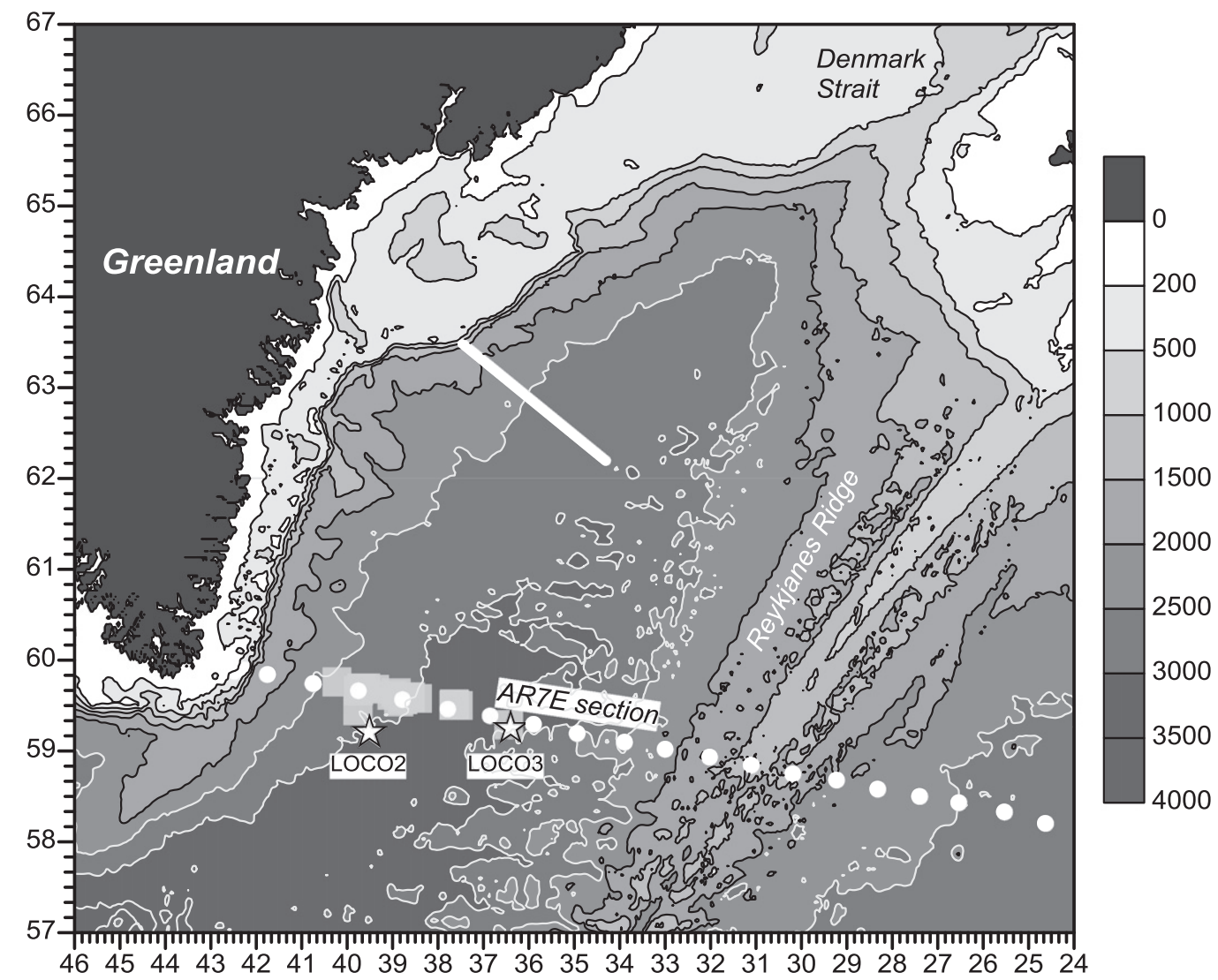

Fig. 1. Topography of the Irminger Sea between Greenland and the Reykjanes Ridge. The hydrographic stations of the AR7E section as it was surveyed in 2011 are shown as white dots. In the Irminger Sea, west of the Reykjanes Ridge, these are typical for all surveys of the WOCE AR7E line since 1990. The mooring locations LOCO2 and LOCO3 where the near bottom temperature and salinity were measured continuously are indicated as stars. The white bar shows the approximate location of the Angmagssalik current meter array, mentioned several times in the text. The grey squares show the locations where since 1991 the lowest near bottom potential temperature was encountered per survey.
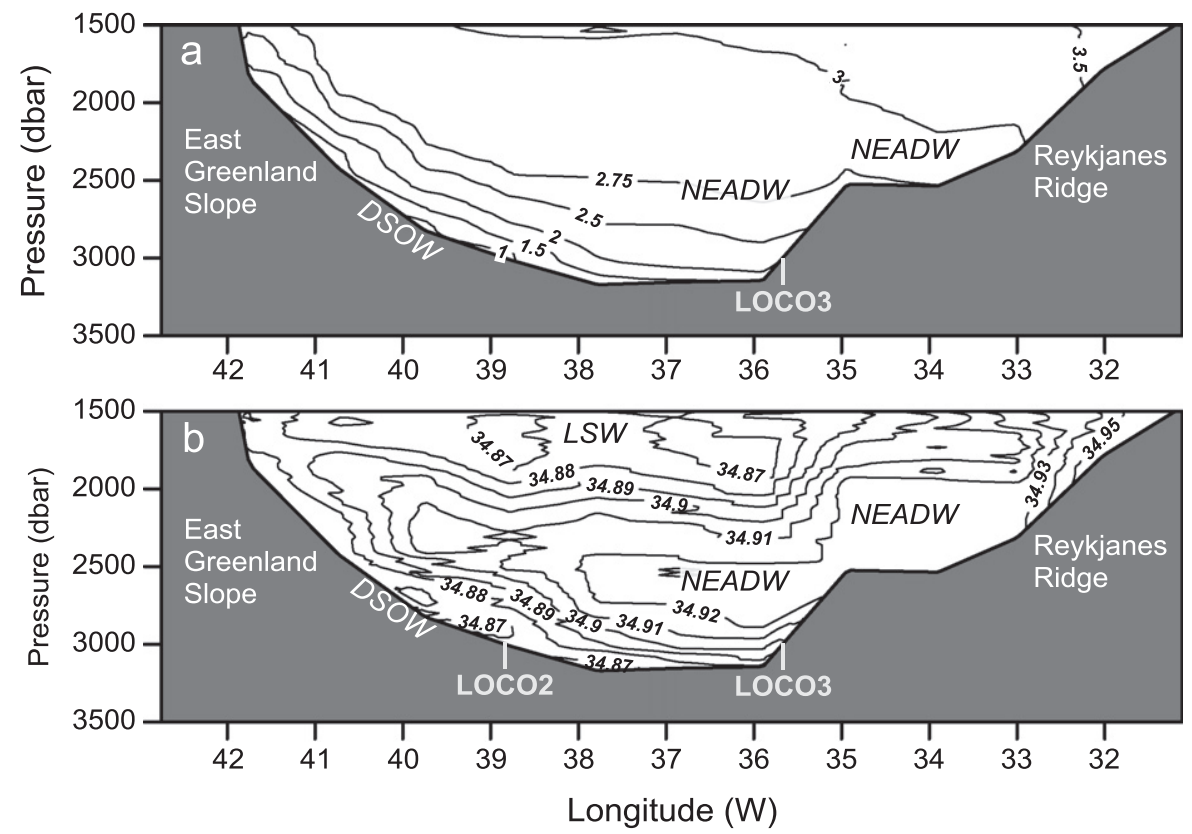

Fig. 2. Vertical distribution of potential temperature (a) and salinity (b) along the AR7E section in the Irminger Sea derived from observations by RV Pelagia in 2000. The acronyms show the location of the main deep water types that contribute to the formation of NADW.

Water (NEADW), a water type characterised by a salinity maximum and a potential temperature of $2.6-2.7^{\circ} \mathrm{C}$ in the 2000-3000 dbar pressure interval. Over the rising western slope of the Reykjanes Ridge, NEADW replaces DSOW as the nearbottom water type. These water types are separated by a nearbottom frontal zone between $35^{\circ}$ and $36^{\circ} \mathrm{W}$ with strong lateral 
gradients in temperature and salinity (Fig. 2). The origin of the NEADW is the Iceland-Scotland Overflow Water (ISOW), formed by overflow of Norwegian Sea deep and intermediate water types across the Iceland-Scotland Ridge, diluted by entrainment of colder and mostly warmer and more saline water (van Aken, 2000). This water type passes from the Iceland Basin into the western Atlantic through the Charlie-Gibbs Fracture Zone at $\sim 52^{\circ} \mathrm{N}$; therefore it is also sometimes named Gibbs Fracture Zone Water. Above the NEADW core we find Labrador Sea Water (LSW), a low salinity water type, formed by deep convection in the Labrador Sea, spreading from there to the neighbouring basins (Yashayaev et al., 2007). Together, DSOW, NEADW, and LSW form the NADW water mass (Dickson and Brown, 1994) that can be found in the Atlantic Ocean across the equator to the latitude of $\sim 30^{\circ} \mathrm{S}$ (Speer and McCartney, 1991).

The hydrographic properties of LSW are known to vary on inter-annual to multi-decadal time scales (Yashayaev, 2007; van Aken et al., 2011). Between the 1970s and the late 1990s a decreasing salinity trend was seen in the LSW in the Irminger Sea, being part of a multi-decadal oscillating trend between 1950 and 2010. Also the DSOW properties at $60^{\circ} \mathrm{N}$, derived from hydrographic surveys, have been reported to vary, showing a decreasing salinity trend of 0.015 per decade from 1963 to 2002, while the NEADW in the Irminger Sea and the ISOW over the eastern slope of the Reykjanes Ridge freshened over that period with a rate of $0.013-0.022$ and 0.008 per decade, respectively (Dickson et al., 2002). This freshening is attributed to a freshening of the source waters of the overflows in the Nordic seas as well as entrainment by the fast flowing turbulent overflows of freshening neighbouring water types, in particular of freshening LSW. In a review paper on abrupt climate change it was noted that this freshening occurs in just the regions critical for sudden shifts in the thermohaline circulation, which has been implicated in many abrupt climate-change events of the past (Alley et al., 2003). However, there is evidence that from 1948 onwards the salinity of the overflow waters was lower than in 1963 (National Research Council, 2002; Boessenkool et al., 2007). Sarafanov et al. (2010) who studied the mean properties of a density defined DSOW, found that in the 1990s and early 2000s the salinity and temperature of the DSOW showed an irregular behaviour without any significant trend. They found some suggestions for an increasing DSOW salinity for the period 2005-2007. Eldevik et al. (2009) found different results for the DSOW in Denmark Strait itself $\left(\sim 67^{\circ} \mathrm{N}\right)$. Hardly any correspondence was seen between the strong freshening at $\sim 60^{\circ} \mathrm{N}$, reported by Dickson et al. (2002), and the DSOW in Denmark Strait where the salinity was dominated by an quasi oscillation with a dominant $\sim 12$ year time scale, and a trend of only -0.033 over a the period $1950-$ 2005 (Eldevik et al., 2009).

There is no single source for DSOW in the Nordic Seas. It has been assumed for a long time that the sources are mainly the saline Atlantic return Water and the fresher Greenland Sea Water with some additional fresher Polar Water in the East Greenland Current north of Denmark Strait, which feed the dense DSOW plume in the Irminger Sea (Eldevik et al., 2009). Recently it became clear from current measurements that about half of the DSOW import may come from a jet-like current north of Iceland, the North Icelandic Jet (Våge et al., 2011). More current measurements are underway to confirm these findings. At relatively short time scales of one to several years the DSOW salinity in the Irminger Sea appears to be correlated with the meridional wind component over Denmark Strait (Holfort and Albrecht, 2007). A weaker southward (northern) wind along Denmark Strait should lead to an increase in the DSOW salinity. Triggered by the wind, different water types are assumed to contribute with changing amounts to the formation of DSOW, leading to the observed changes in the salinity of DSOW. This agrees with the statement by Eldevik et al. (2009) that the varying DSOW properties are mainly determined by varying ratios of the source waters. They also assume that changes in wind forcing and a resulting variable circulation are responsible for that variation. Sarafanov et al. (2010) suggest that changing properties of the overlying water, entrained into the overflow plumes, also contribute to the observed variability.

Six years of continuous measurements of the near bottom salinity over the East Greenland slope near at the Angmagssalik array at $\sim 63^{\circ} \mathrm{N}$ (Fig. 1, white bar) from the summer of 1998 to the summer of 2005 (with a 1 year data gap in 1999-2000) have revealed intra-annual variability (Dickson et al., 2008; Hall et al., 2011). Extreme freshening events by about 0.1 were observed between January and July in both 1999 and 2004. In other years that spring freshening, although present (e.g. 2002), was a factor of 2.5-5 smaller. Comparison of these continuous data with the salinity data and meridional wind data by Holfort and Albrecht (2007) has revealed that the extreme freshening events with a time scale of about 6 months are also correlated with the meridional wind events over Denmark Strait (Dickson et al., 2008). Comparison of the data with an OCCAM model simulation suggests that the cause of the 2004 low-salinity anomaly is not an increase in upstream net freshwater input but a wind driven increase in volume flux of low salinity water, with a high potential density, at around $75^{\circ} \mathrm{N}, 20^{\circ} \mathrm{W}$ four and a half months earlier, and an associated spin-up of the Greenland Sea Gyre (Hall et al., 2011). Temperature variation of DSOW is less well described, but from temperature measurements by a current meter array in and out of the DSOW core, also at $\sim 63^{\circ} \mathrm{N}$, Dickson et al. (1999) derived a considerable variability in temperature of the bottom layer over the slope.

\section{Data}

Since 1990 near-annual CTD surveys of the WOCE Hydrographic Program section AR7E (Fig. 1), running from the southern tip of Greenland near Cape Farewell to Ireland, have been performed (See Table 1). After the end of the WOCE field phase in 1997 these surveys were continued as a contribution to CLIVAR or were part of a variety of international programmes like "Variability of Exchanges in the Northern Seas" (VEINS),

Table 1

Hydrographic surveys of the AR7E section, used in this paper.

\begin{tabular}{|c|c|c|}
\hline year & Research Vessel & Cruise Code \\
\hline 1991 & RV Tyro & 64TR91/1 \\
\hline 1991 & RRS. Charles Darwin & $74 \mathrm{AB} 62 / 1$ \\
\hline 1991 & FS Meteor & 06MT18_1 \\
\hline 1992 & FS Valdivia & 06AZ129/1 \\
\hline 1994 & FS Meteor & 06MT30_3 \\
\hline 1995 & FS Valdivia & 06AZ152 \\
\hline 1996 & FS Valdivia & 06AZ161/2 \\
\hline 1997 & FS Meteor & 06МТ039 \\
\hline 1999 & FS Valdivia & 06AZ179 \\
\hline 2000 & RV Pelagia & 64PE169 \\
\hline 2000 & FS Poseidon & $06 \mathrm{PO} 263$ \\
\hline 2001 & FS Meteor & 06МT050/3 \\
\hline 2002 & FS A. von Humboldt & 07AL2002_05 \\
\hline 2003 & RV Pelagia & 64PE216 \\
\hline 2004 & FS A. von Humboldt & 07AL2004_1 \\
\hline 2005 & RV Pelagia & 64PE240 \\
\hline 2006 & RRS Discovery & 74DI309-310 \\
\hline 2007 & RV Pelagia & 64PE275 \\
\hline 2008 & RRS Discovery & 74DI332 \\
\hline 2009 & RV Pelagia & 64PE312 \\
\hline 2010 & FS Meteor & 06MT82/1 \\
\hline 2011 & RV Pelagia & 64PE342 \\
\hline
\end{tabular}


"Arctic-Subarctic Ocean Fluxes" (ASOF), and as of lately "Thermohaline Overturning - at Risk?" (THOR). These data are public and are available from different data bases. The data quality of these surveys is expected to meet the WOCE quality requirements, which are accuracy for the temperature of $0.005{ }^{\circ} \mathrm{C}$ and a precision of $0.002{ }^{\circ} \mathrm{C}$ or better and for the salinity an accuracy of 0.002 and a precision of 0.001 (Joyce and Corry, 1994). With the advance of electronic reference thermometers instead of reversing mercury thermometers, this typical temperature accuracy is likely to have become better than in the older measurements from the 1970s and before.

From each survey the near bottom temperatures in the Irminger Sea were analysed, and the location with lowest potential temperature was designated the "core" of the DSOW flow across the section. Dickson et al. (2002) have published a time series of salinity of the DSOW core in different basins from 1963 to 2001. This salinity series for the western Irminger Sea that also contains the East Greenland slope near $60^{\circ} \mathrm{N}$ is referred to here as the "Dickson series". We have extended that series further backwards with salinity data since 1950 obtained from the World Ocean Data Center, here referred to as the pre-Dickson data. The resolution of the temperature and salinity data in this data set is respectively $0.01{ }^{\circ} \mathrm{C}$ and $0.01 \%$.

To support the interpretation of the annual hydrographic data, and to improve the insight into the variations in DSOW properties at short time scales, the temperature and salinity of the near bottom water was measured from 2003 onwards at two locations in the Irminger Sea near the AR7E section. These were measured by means of an SBE Microcat P-T-S recorder, mounted at $\sim 15 \mathrm{~m}$ above the bottom: moorings LOCO2 at $59^{\circ} 12.2^{\prime} \mathrm{N}, 39^{\circ} 30.3^{\prime} \mathrm{W}$ and LOCO3 at $59^{\circ} 13.0^{\prime} \mathrm{N}, 36^{\circ} 19.9^{\prime} \mathrm{W}$, part of the "Long-term Ocean Climate Observations" programme (LOCO), both deployed near the $3000 \mathrm{~m}$ isobath (the stars in Fig. 1). The calibration of the
Microcat data was performed by a comparison with data from the CTD before and after each deployment period. The data were recorded every 3-5 min. In order to remove most of the tidal signal in the resulting data, 24 hours mean values of the data were constructed.

\section{Results}

\subsection{Hydrographic surveys}

The locations where the lowest near-bottom potential temperature, the "DSOW core", was encountered during hydrographic surveys of the AR7E section since 1991, range over the whole width of the deep Irminger Sea (Fig. 1, grey squares); from the East Greenland slope at a depth of $\sim 2600 \mathrm{~m}$ through the abyssal plain to the rise of the Reykjanes Ridge near the $3100 \mathrm{~m}$ isobath. At $\sim 60^{\circ} \mathrm{N}$ the DSOW core apparently is not found at a fixed position on the slope. The core positions in the deep basin, east of the $3100 \mathrm{~m}$ isobath at the foot of the East Greenland slope, were observed in 1991, 1992, 1999, and 2006, indicating that the coldest DSOW core is not restricted to the fast-flowing area over the continental slope. Eastward motion or even recirculation of DSOW apparently spreads cold DSOW over the abyssal plain in the Irminger Sea.

The AR7E time series of potential temperature and salinity of the DSOW core (Fig. 3a and b) show mean values (and standard deviations $)$ of $1.049{ }^{\circ} \mathrm{C}( \pm 0.129)$ and $34.881( \pm 0.012)$, respectively, at $59.6^{\circ} \mathrm{N}\left( \pm 0.1^{\circ}\right), 38.7^{\circ} \mathrm{W}\left( \pm 0.9^{\circ}\right)$. The shallowest level where the core was observed is over the East Greenland slope at a pressure of $2656 \mathrm{dbar}$. The density effect of the temperature standard deviation is twice the density effect of the salinity standard deviation. However, a linear regression of the salinity versus the potential temperature shows that the slope of this
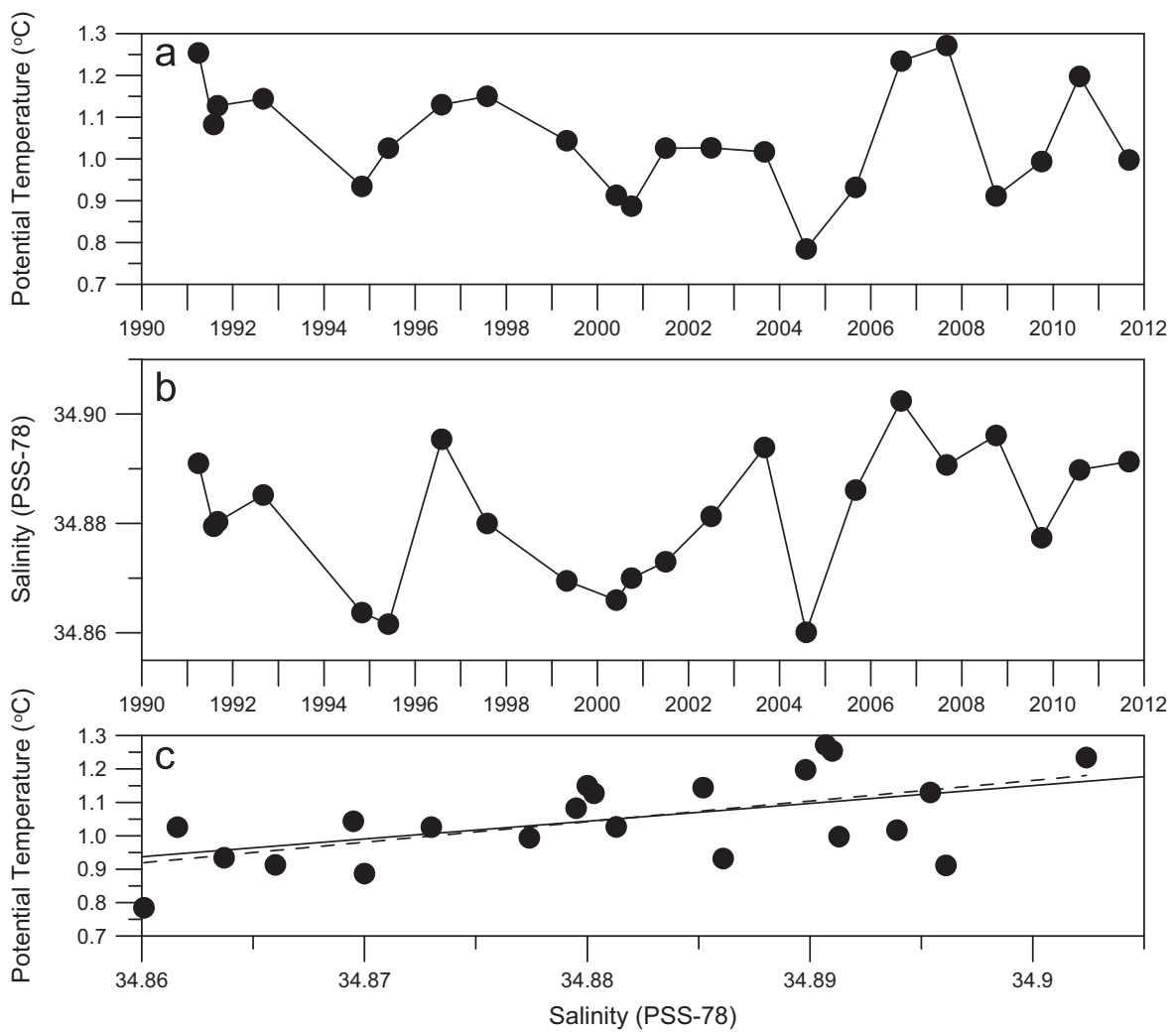

Fig. 3. Time series of the temperature (a), salinity (b) and the $\Theta-S$ diagram (c) of the core of the DSOW, derived from the near-annual surveys of the WOCE AR7E section in the Irminger Sea. This core was defined as the location where, during a survey, the lowest near bottom potential temperature was recorded. The dashed line in (c) shows the linear regression between both parameters, the full line represents the $41.67 \mathrm{~kg} / \mathrm{m}^{3}$ isopycnal of the potential density anomaly relative to $3000 \mathrm{dbar}$. 
regression does not differ significantly from the $\sigma_{3}=41.67 \mathrm{~kg} / \mathrm{m}^{3}$ isopycnal, as in indicated in Fig. 3c. Over the period 1991-2011 neither the linear temperature trend nor the salinity trend are significant, in contrast to the significant long-term salinity decrease of DSOW presented by Dickson et al. (2002) for the period 1963-2002. The dominant time scale of the temperature variations, shown in Fig. 3a, can be estimated from time lagged autocorrelations as well as from the period between successive maxima and minima. Both methods give a similar result, a dominant time scale of 4-5 years. This agrees well with the typical time scale for the temperature variations of the DSOW layer in the Labrador Sea between 1986 and 2005 derived by Yashayaev and Dickson (2008) from annual hydrographic surveys (their Figure 21.3).

Comparison of our DSOW salinities from 1991 to 2011 with the partly overlapping data presented by Dickson et al. (2002) reveals that in the overlapping 12 years period they are coherent (Black and grey dots in Fig. 4), as can be expected from the use of the same surveys in this period. Apparently, the significant decrease of the DSOW salinity from the early 1970s onwards had turned into a constant or even slightly increasing mode after 1995. However, in the period 1963-1969 there was also a rising tendency of the DSOW salinity in the Dickson data. When we extend our time series backwards to 1950 with data points, derived from nearby hydrographic sections available from the World Ocean Data Center (pre-Dickson squares in Fig. 4) it appears that the DSOW salinity was at a long-term maximum in the early 1970s. A synthesis of the different data sets and the application of a 9 years running mean (thick line in Fig. 4) show that the salinity of the DSOW displays a similar multi-decadal variation as was observed for the LSW at $1500 \mathrm{~m}$ depth (van Aken et al., 2011). This may be due to either a coherent salinity variation of the source waters of both water types, or to a direct interaction between them, e.g. by mixing or entrainment (Dickson et al., 2002). Since this multi-decadal variation is observed in the source water types of both the lower and the middle NADW, it can be expected that this variation can also be observed in the NADW properties at lower latitudes, as shown by e.g. van Sebille et al. (2011). It was already mentioned before, that Eldevik et al. (2009) have reported a $\sim 12$ year quasi-periodic salinity variation for the overflow water in Denmark Strait itself. The salinity range in this variation amounted to approximately 0.04 , similar to our range of the multi-decadal variations. However the $\sim 12$ year quasi-periodicity cannot be recognised in our data (Fig. 4). Therefore it is likely that the long-term behaviour of the DSOW salinity is strongly influenced by water types, incorporated after leaving the sill area in Denmark Strait, e.g. NEADW and/or LSW.

\subsection{Continuous Observations}

The moorings LOCO2 and LOCO3, both fitted with a nearbottom Microcat to measure continuously (every 3-5 min) the salinity and temperature of the DSOW, were both deployed near the $3000 \mathrm{~m}$ isobath, close to the mean depth of the coldest water in the DSOW core. However, contrary to the search for the coldest bottom water encountered during a hydrographic survey, a fixed position T-S sensor will not necessarily be in that coldest core during part or most of the time. Comparison of the LOCO2 data with the DSOW core data from the AR7E surveys shows that on average the continuously measured temperature at $\mathrm{LOCO} 2$ is about $0.1^{\circ} \mathrm{C}$ warmer than the DSOW core and 0.004 more saline (Fig. 5). Apart from that systematic difference, the annual CTD data follow the long-term development of temperature and salinity that can be derived from the continuous observations. In both the AR7E data and in the running annual mean temperature at $\mathrm{LOCO} 2$ the maximum temperature is found in 2007. However, the AR7E data are still seriously hampered by aliasing of intra-annual variability to inter-annual time scales, shown by the comparison of the 1 year running mean with the AR7E data points. For instance, since the surveys were mainly in summer, the AR7E data occasionally coincided with the temperature minimum from the annual cycle, discussed below, causing the AR7E data points to fall about $0.2{ }^{\circ} \mathrm{C}$ below the annually filtered LOCO2 temperatures (thick line in Fig. 5a).

A feature that attracts the attention is the apparent presence of an annual cycle in the DSOW temperature, with a sudden cooling of on average $0.2^{\circ} \mathrm{C}$ in late summer, followed by a steady increase from the winter to the following summer. The mean annual cycle of the DSOW temperature (dots in Fig. 6), based on the 7 year averaged monthly mean temperatures, has a range of $0.16{ }^{\circ} \mathrm{C}$. The annual temperature curves (thin lines in Fig. 6) show a variation of the months with warmest and coldest temperatures. The average temperature curve still is asymmetric. The on average strongest cooling occurs from July to September. After one more cooling month, the mean temperature minimum is reached in October. From December onwards a steady warming occurs until the maximum temperature is found in May, after which only a slight cooling takes place in the following two months. With a typical meridional velocity in the advection of DSOW anomalies of 56 day per $1^{\circ}$ latitude $(=3.4 \mathrm{~cm} / \mathrm{s}$ along the DSOW path (Holforth and Albrecht, 2007)), this suggests a maximum temperature of the source water of DSOW in Denmark Strait at $66^{\circ} \mathrm{N}$ about 11 months earlier, in the preceding early summer.

At even shorter time scales still a lot of temperature variance is encountered. The temperature anomaly, relative to a 10 day running mean, has standard deviation of $0.04{ }^{\circ} \mathrm{C}$. This value

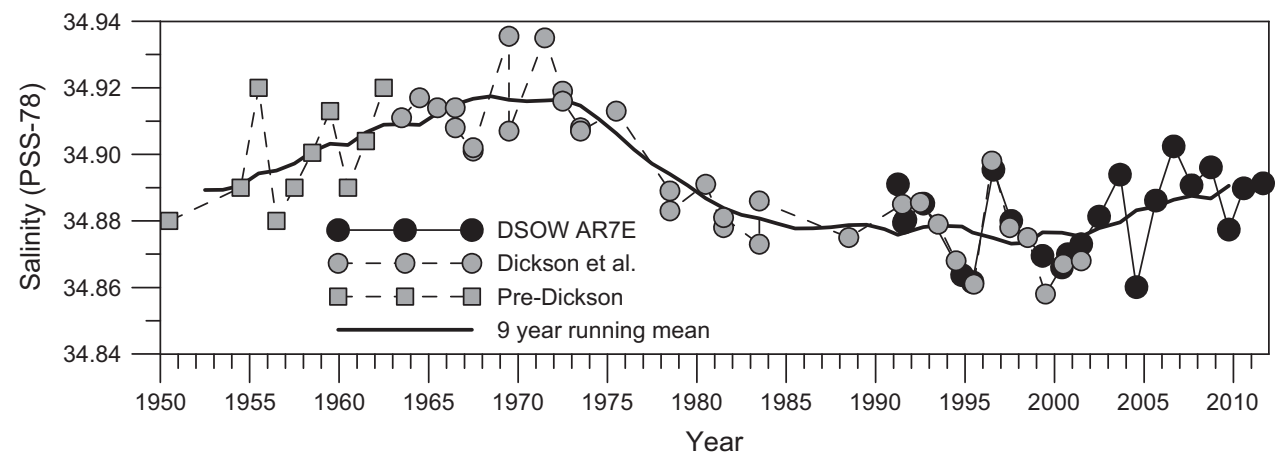

Fig. 4. Combined time series of the DSOW salinity from the AR7E surveys (black dots), the DSOW salinities presented by Dickson et al. (2002) (grey dots), and from hydrographic stations near $60^{\circ} \mathrm{N}$ from preceding years, available from the Wold Ocean Data Center (grey squares). The thick line shows the 9 year running mean of the combination of the data points from the three different data sets. 

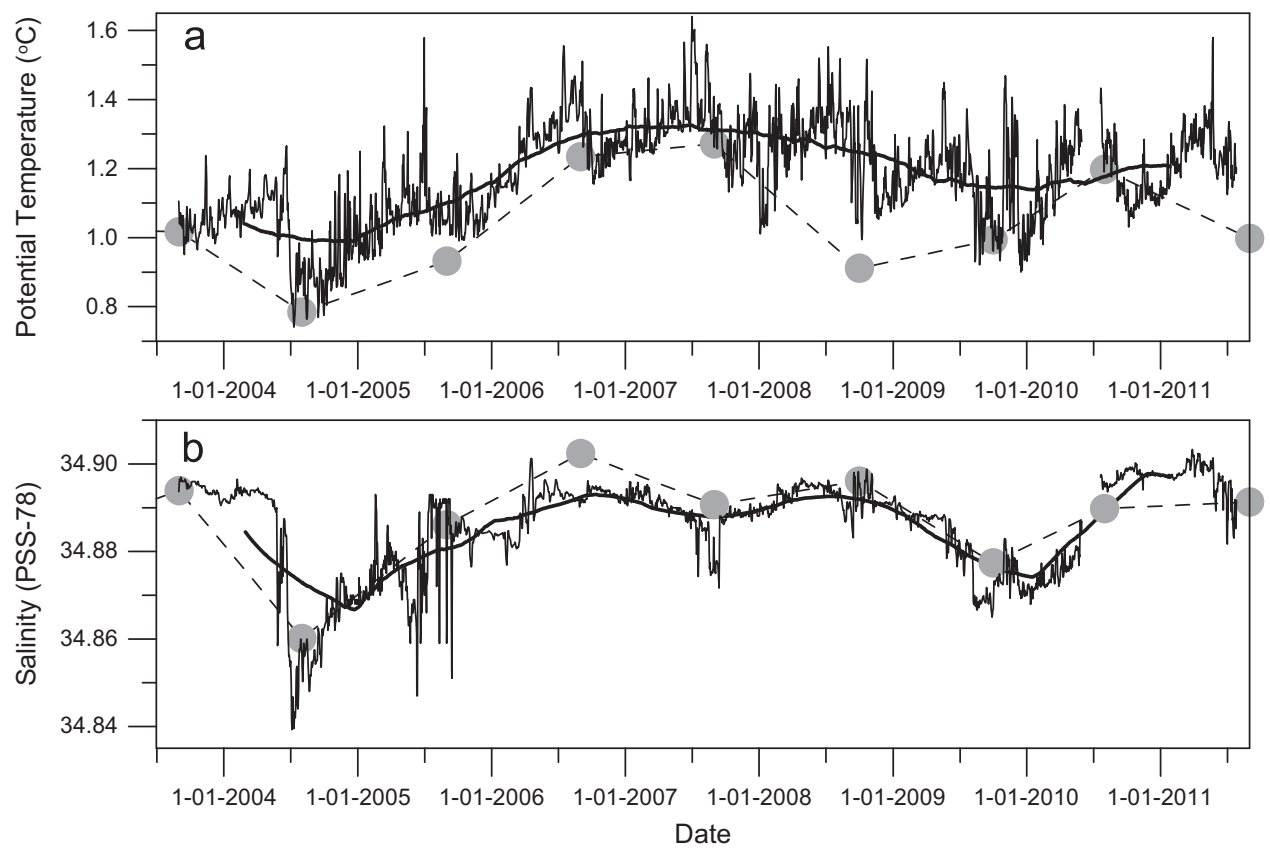

Fig. 5. Time series of the near bottom ( $15 \mathrm{~m}$ ) temperature (a) and salinity (b) at mooring LOCO2. The grey dots and dashed line shows the data points of the coldest DSOW core, encountered during annual surveys of the AR7E section. The thick lines show the 1 year running mean values of LOCO2, also referred to as long-term values.

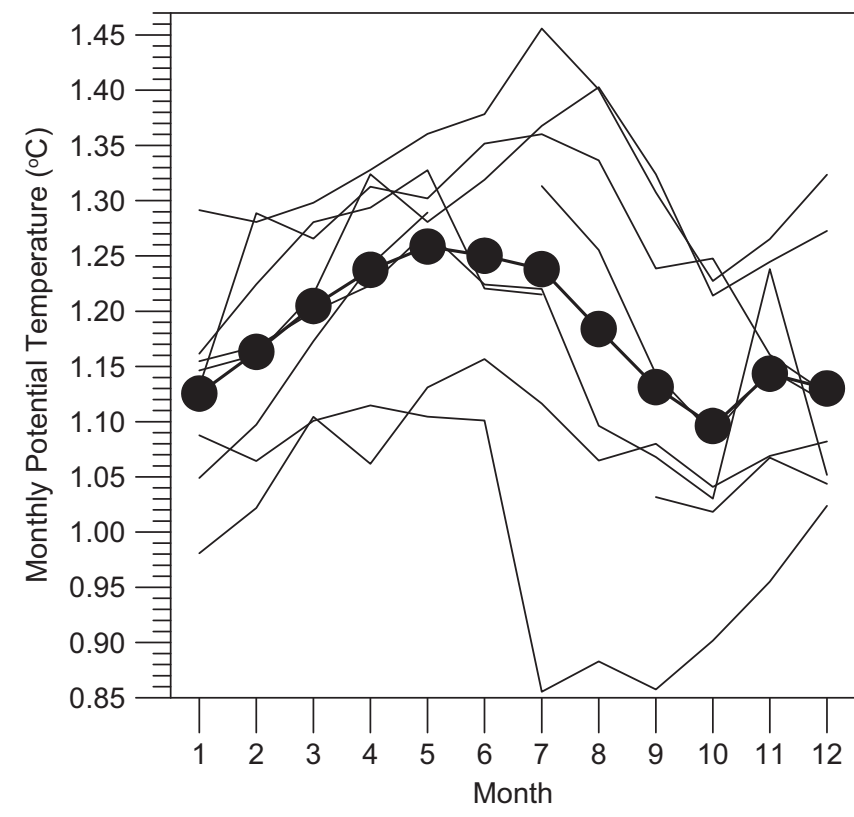

Fig. 6. The annual cycle of the near-bottom temperature at mooring LOCO2, derived from the 7 year averaged monthly mean temperatures (Dots). The Thin lines show the monthly mean values for the individual years.

compares well with the standard deviation of the annual cycle, $0.05{ }^{\circ} \mathrm{C}$. The bulk of the DSOW temperature variation is caused by the inter-annual variability, depicted by the thick line in Fig. 5a, with a standard deviation of slightly over $0.10^{\circ} \mathrm{C}$. The time lagged autocorrelation of the high-frequency part of the LOCO2 data (not shown) suggests a typical time scale of that variability on about 8 day, close to the 10 day cut-off time scale. The cause of such "weekly" variations with time scales from 1 to 10 day may be sought in lateral shifts of a meandering DSOW core, or in existing inhomogeneities within the DSOW layer itself. However, no significant correlation could be established between the high-frequency velocity components and the high-frequency temperature and salinity signals, or with their derivatives. This indicates that the observed high-frequency hydrographic variability is probably not locally generated.

The salinity shows definitely less high-frequency variability, and that variability is not significantly correlated with the highfrequency temperature variability $(R=0.13)$ The anomaly relative to a 10 day running mean as well as the annual cycle both have standard deviations of only 0.002 , small relative to a standard deviation of 0.008 for the inter-annual variability (thick line in Fig. 5b). An annual cycle cannot be recognised directly, since the salinity record is dominated by two relatively large freshening events. The freshening event in 2004 was quite sudden and asymmetric. In 48 day, from 24 May to 9 July 2004, the salinity decreased with 0.050 , coincident with a sudden temperature decrease of $0.42{ }^{\circ} \mathrm{C}$. The resulting salinity minimum at LOCO2 can be identified with as similar minimum, encountered at 3 moorings of the Angmagssalik array, spanning a distance of about $40 \mathrm{~km}$ at $\sim 63^{\circ} \mathrm{N}$ around 1 May 2004 (Dickson et al., 2008; Hall et al., 2011). The 40 day transfer of this minimum over $3^{\circ}$ latitude suggests a definitely higher advection velocity for anomalies ( $1^{\circ}$ per 23 day or about $6.4 \mathrm{~cm} / \mathrm{s}$ ) than the velocity of $1^{\circ}$ per 56 day, proposed by Holfort and Albrecht (2007). However, they based their estimate not on a single anomaly but on a series of anomalies. The recovery of the salinity minimum to the typical salinity values before 24 May 2004 took considerably more time; the salinity crossed the 34.89 level again on 15 July 2005, more than one year later. The magnitude of the sudden salinity decrease is half the magnitude observed at the Angmagssalik array at $63^{\circ} \mathrm{N}$. This reduction is probably due to ongoing mixing of DSOW with the overlying more saline NEADW. Also in 2009 a deep salinity minimum was encountered, although not as low as in 2004. The formation of that minimum lasted longer, during 82 day from 23 May until 12 August 2009 the salinity decreased with 0.020 , again coinciding with a sudden temperature fall, with $0.43{ }^{\circ} \mathrm{C}$. Also here the recovery to former salinity levels lasted longer, at least until 31 May 2010. Other salinity minima occurred at $\mathrm{LOCO} 2$, but all with a definitely smaller magnitude. However, not all sudden salinity decreases were accompanied by temperature decreases, and the sudden temperature decreases were not 
always accompanied by salinity decreases. Occasionally a sudden temperature decrease is accompanied by a sudden small salinity increase. This complicates the search for a single cause of these abrupt changes.

Because of the long recovery time for the salinity minima from 2004 to 2009 and their exceptional magnitude, the inter-annual variability of the salinity is dominated by these two events (thick line in Fig. 5b). The correlation of the annually smoothed temperature with the annually smoothed salinity signal $(R=0.84)$ is marginally significant at the $p=2.5 \%$ level. The longterm (annually averaged) salinity minima from December 2004 and January 2010 coincided with temperature minima (Thick lines in Fig. 5). In the period 2006-2008, the potential temperature was relatively high, $>1.2{ }^{\circ} \mathrm{C}$, while also relatively high salinities were encountered.

The continuous temperature records from the $\mathrm{LOCO} 3$ position (Fig. 7) show higher temperatures and a larger temperature range than data from LOCO2. The standard deviation of the potential temperature $\left(0.33^{\circ} \mathrm{C}\right)$ is over twice the standard deviation at LOCO $2\left(0.15^{\circ} \mathrm{C}\right)$. At LOCO3 the inter-annual variation (thick lines in Fig. 7a) has a standard deviation of only $28 \%$ of the standard deviation of the complete signals, compared to $71 \%$ for LOCO2. This relatively high standard deviation at LOCO2 is mainly due to stronger short-term changes, since the inter-annual variability standard deviation at LOCO3 is only $0.09{ }^{\circ} \mathrm{C}$, against $0.10^{\circ} \mathrm{C}$ for LOCO2, about similar values. The differences between $\mathrm{LOCO} 3$ and LOCO2 indicate that in the eastern Irminger Sea the processes, dominantly responsible for the hydrographic variability, probably differ from those which determine the variability near the East Greenland slope. The relatively high values of the potential temperature $\left(>2{ }^{\circ} \mathrm{C}\right)$ which regularly occur, suggest that the temperature variations at the $\mathrm{LOCO} 3$ position are due to zonal shifts of the frontal boundary between DSOW and NEADW at the foot of the Reykjanes Ridge (see e.g. Fig. 2).

The salinity signal at LOCO3 has a standard deviation of 0.014 , in magnitude comparable to the value of 0.011 for LOCO2, contrary to the temperature signal at LOCO3. The contrast between DSOW and NEADW, which is probably responsible for most of the observed variability at LOCO3, is also dominated by the temperature. The inter-annual variation of potential temperature and salinity at LOCO3 (standard deviations $0.29{ }^{\circ} \mathrm{C}$ and 0.005 , respectively) is certainly not in phase with that variation at LOCO2; the first has minima in spring and summer 2005 while the latter had minima in December 2004 and high values after December 2005. This may be due to a delay because of the time advection takes to bring DSOW from the Greenland slope to the eastern part of the basin or to the different causes of the hydrographic variability in the bottom layers of the eastern and western regions of the Irminger Sea.

\subsection{The thermohaline structure of the DSOW variability}

If we plot the potential temperature versus the salinity for the coldest near-bottom samples per survey (big black dots in Fig. 8), they are grouped around a more or less straight line. As mentioned before, with reference to Fig. 3c, a linear regression for these data points shows that such a linear relation is significant $(R=0.59, N=22)$. Within the accuracy of the estimates of the regression coefficients, that relation equals the isopycnal relation for $\sigma_{3}=41.67 \mathrm{~kg} / \mathrm{m}^{3}$ (the thick line in Fig. 8). Apparently, this isopycnal connects two endpoints, a relatively saline and a relatively fresh variety of DSOW near $\sim 60^{\circ} \mathrm{N}$, DSOW $\mathrm{S}$ and $\mathrm{DSOW}_{\mathrm{F}}$ respectively, endpoints that also were proposed by Tanhua et al. (2005) to contribute to the formation of DSOW.

All near-bottom water samples along the AR7E line between the East-Greenland slope and the Reykjanes Ridge (big grey dots in Fig. 8) show that at that section regular warmer near-bottom water is observed with only limited salinity deviations, like a mixture of high density, cold DSOW with lower-density overlying water types. Over the rise of the Reykjanes Ridge occasionally a "pure" form of relatively warm NEADW $\left(\theta>2.5^{\circ} \mathrm{N}\right)$ is encountered in the near-bottom layers. The data points for LOCO2 (small grey points in Fig. 8) are scattered also near-parallel to the isopycnals, but at a slightly lower density $\left(41.65 \mathrm{~kg} / \mathrm{m}^{3}\right)$.

The data points for mooring LOCO3 (small black dots in Fig. 8) mainly reflect the high-frequency alteration between cold DSOW
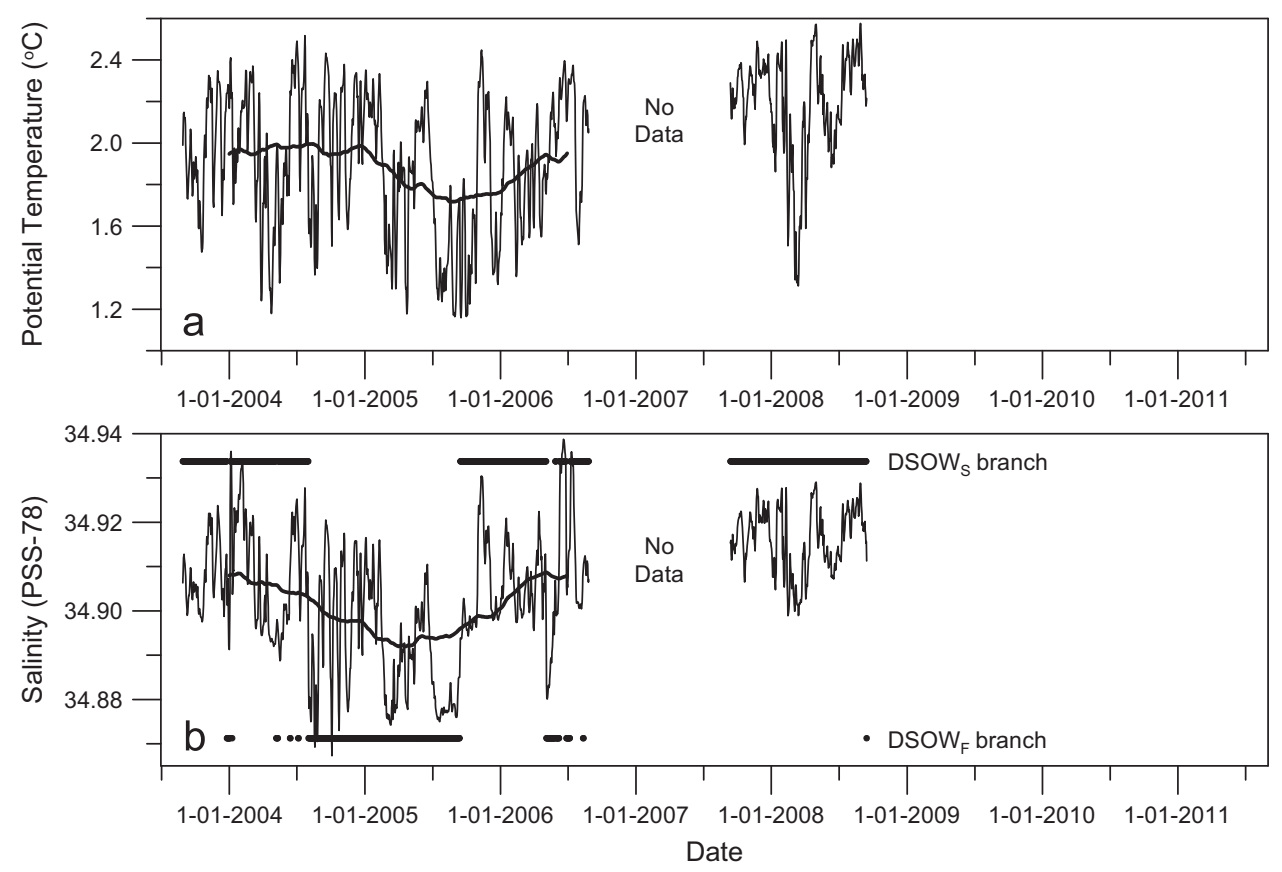

Fig. 7. Time series of the near bottom $(15 \mathrm{~m}$ ) temperature (a) and salinity (b) at mooring LOCO3. The thick lines show the 1 year running mean values. The black dots in

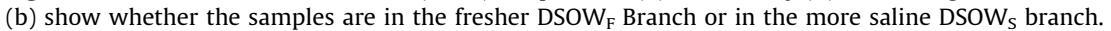




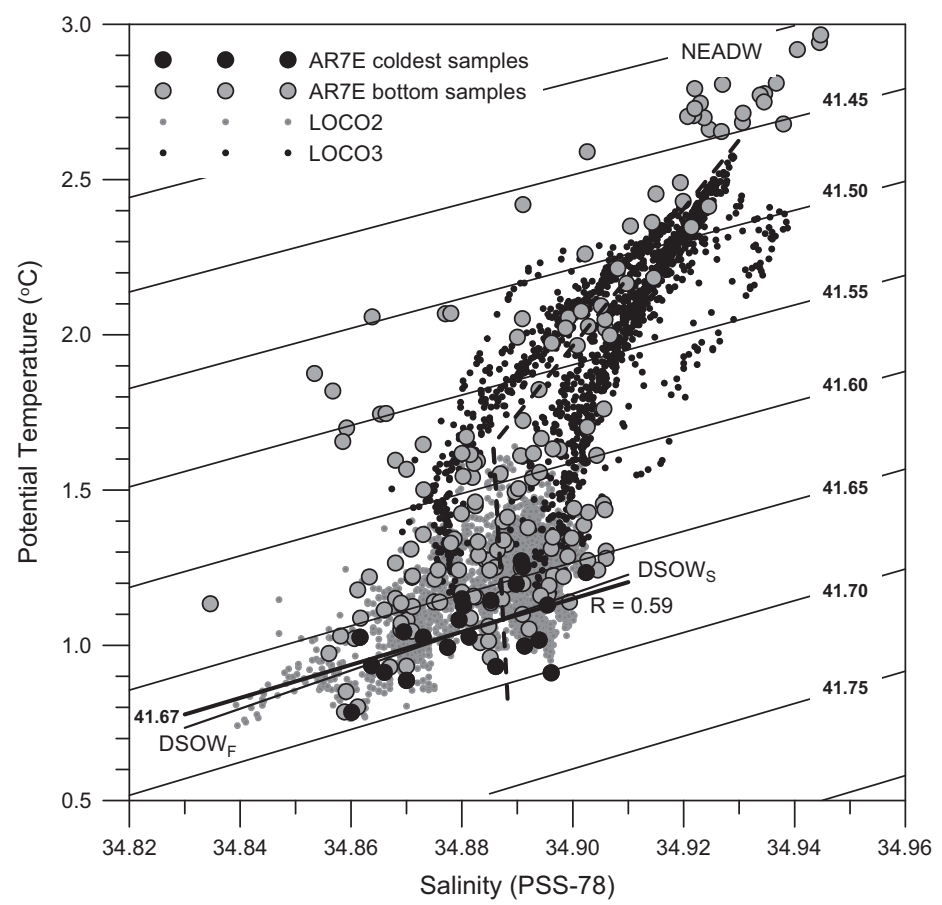

Fig. 8. Potential temperature-Salinity diagram of the near bottom water in the Irminger Sea. Big black dots: coldest water per survey of the AR7E section; big grey dots: all near-bottom samples between the East Greenland Slope below 2500 dbar and the Reykjanes Ridge; small grey dots: the bottom water near the East Greenland slope at LOCO2; small black dots: the bottom water near the Reykjanes Ridge at LOCO3. The series of thin lines show the isopycnals for the potential density anomaly relative to a pressure of $3000 \mathrm{dbar}$ in $\mathrm{kg} / \mathrm{m}^{3}$. The thin straight line shows the linear regression for the coldest water samples per survey while the thick line shows the $41.67 \mathrm{~kg} / \mathrm{m}^{3}$ isopycnal, also shown in Fig. 3c. The dashed line depicts the division between the high-salinity DSOW dominated water and low salinity DSOW $\mathrm{F}_{\mathrm{F}}$ dominated water at LOCO3.

and warmer NEADW, which are separated by a near bottom front at the rise of the Reykjanes Ridge close to the LOCO3 location (Fig. 2). In general the temperatures from LOCO2 are below the $1.5^{\circ} \mathrm{C}$. Therefore the overlap of the $\mathrm{LOCO} 2$ and LOCO3 data points is quite limited. Occasionally nearly "pure" DSOW is encountered at $3000 \mathrm{~m}$ at LOCO3, but at most times the bottom water is a mixture of DSOW and NEADW, or even nearly pure NEADW. So it is likely that shifts in the frontal location are the main cause of the dominant alteration of cold and warmer water in the bottom layer of LOCO3. Because of the dominance of this high frequency variability, the $\mathrm{LOCO} 2$ and $\mathrm{LOCO} 3$ records show no significant direct correlation. The bi-modal distribution of the salinity of the LOCO3 data points at intermediate temperatures reveals that these branches of points connect NEADW with either DSOW $\mathrm{F}_{\mathrm{F}}$ or DSOW $_{\mathrm{S}}$. The dashed line in Fig. 8 makes the distinction between both branches of LOCO3 data points. The locations of the black points in Fig. 7b show whether the data point can be attributed to the fresher or the saltier branch. It appears that during the relatively cold and fresh period at $\mathrm{LOCO} 2$ from the summer of 2004 to the summer of 2005 coincides with the dominance of the DSOW $\mathrm{F}_{\mathrm{F}}$ connected branch of data points for LOCO3, with a delay of $\sim 2$ months ( \pm 2 weeks).

\section{Discussion}

The DSOW that passes through the Irminger Sea is the densest water type that contributes to the formation of NADW, the water mass that constitutes the cold branch of the density driven AMOC that fills the deep Atlantic Ocean and spreads worldwide (Dickson and Brown, 1994). For some water types encountered in the Irminger Sea the hydrographic variability is well described; Subarctic Mode Water (De Jong, 2010) and Labrador Sea Water (Yashayaev et al., 2007; van Aken et al., 2011) show variations on inter-annual to multi-decadal scales. Hydrographic surveys near $60^{\circ} \mathrm{N}$ since 1950 also show an oscillation of the salinity of DSOW from 1950 until 2011, with initially a period with increasing salinity until a high salinities are reached around 1970 (9 year running mean, thick line in Fig. 4). From then on the level of the DSOW salinity declined until the period with low salinities in the late 1990. Since these years the salinities increased until present, when the salinity has come back to the values from the early 1950s. This long-term salinity change runs nearly in phase with the variation of the LSW variability, described by Yashayaev (2007) and van Aken et al. (2011). Earlier reports on long-term freshening trends of the DSOW are based on shorter time series, which were not able to resolve the $\sim 60$ year time scale but only the descending trend from 1970 to 2000 (e.g. Dickson et al. (2002)). The cause of this long-term variation is not known. It is possible that it is related to a long-term variation of the hydrographic properties of the source waters, reflecting an overall salinity change in the northern North Atlantic, driven either by air-sea interaction and atmospheric forcing or by variation of large-scale advection patterns. Another possibility is a change in the mutual ratio of different source waters that contribute to the formation of DSOW, as has also been noted for ISOW (Eldevik et al., 2009). For the latter water mass a significant correlation between the salinity and the mean North Atlantic Oscillation (NAO) winter (DJFM) index over the preceding 8 years was mentioned by Sarafanov (2009) and Sarafanov et al. (2010). In case of the DSOW variations, presented here, it may be a wind driven alteration of the ratio of waters from the East Greenland Current and from the Iceland Sea via the North Icelandic Jet (Jonsson and Valdimarsson, 2004; Eldevik et al., 2009; Våge et al., 2011). The NAO salinity seems to be well (negatively) correlated with the 10 year running mean of the NAO index $(R=0.70)$, with a delay of 4 year, similar to the ISOW index, reported by Sarafanov et al. (2010). However, since both the DSOW salinity (Fig. 4) and 
the 10 year running mean of the NAO index for the period 19502011 are dominated by variations with the time-scale of the 62 year record length, this strongly reduces the number of the degrees of freedom, making it is questionable whether that correlation is significant or not. A less statistical, more mechanistic approach is required to find the cause of the long-term salinity variation.

On top of this multi-decadal hydrographic variation, variations with decadal to inter-annual time scales are recognised from the near-annual surveys of the AR7E section (Fig. 3). Here, however, we stumble to a problem inherent in the use of hydrographic surveys with research vessels. They are at best carried out annually and mainly in summer for reasons of weather and sea ice distribution, e.g. the surveys of the WOCE AR7E section since 1991. The interpretation of data from such surveys may be hampered by aliasing of strong intra-annual variations of temperature or salinity which may be interpreted as variations at much longer inter-annual time scales or even, by aliasing of the annual temperature cycle, as a systematic, permanent offset. However, such hydrographic surveys reveal at least the spatial structure of the DSOW, e.g. Fig. 1 (grey squares) and Fig. 2. An alternative for hydrographic surveys, moored instrumentation, does resolve the shorter time scales. When the moored instruments are located close to the mean core of the DSOW, only relatively small systematic differences will exist with the laterally shifting DSOW core, as in mooring LOCO2. When, however, the moored instruments are close to a lateral boundary of the DSOW core, the hydrographic variations may be strong, but mainly reflect shifts of the front between the DSOW core and the neighbouring NEADW like in mooring LOCO3. Only by discriminating between the DSOW $\mathrm{F}_{\mathrm{F}}$ and $\mathrm{DSOW}_{\mathrm{S}}$ dominated branches of data points, left and right of the dashed line in Fig. 8, we are able to show that those different endpoints also contribute to the overall hydrographic variability at the rise of the Reykjanes Ridge.

For the period 1998 until 2011 three strong freshening events $\left(\Delta S \approx 0.05\right.$ at $\sim 60^{\circ} \mathrm{N}$ ) have been recorded (Hall et al., 2011 and this research). That suggests one freshening event every 4 years. The annual surveys, shown in Fig. 3b, indicate that at least one other freshening event occurred in 1994. Then the mean occurrence of such freshening events would become once every 5 years. The range of DSOW hydrographic core properties, shown in Fig. 8 (big black dots) illustrates the range from freshening events $\left(\mathrm{DSOW}_{\mathrm{F}}\right)$ to "normal" circumstances $\left(\mathrm{DSOW}_{\mathrm{S}}\right)$. According to Holfort and Albrecht (2007) and Hall et al. (2011) the freshening events correlate with strong southerly winds upstream of the sill in Denmark Strait. Different paths for the supply of source waters for the DSOW may be involved here. They flow either directly via the East Greenland Current over the East Greenland slope (e.g. Rudels et al. (2002)) or via the North Icelandic Jet, a current from the Iceland Sea over the slope off northwest Iceland (Jonsson and Valdimarsson, 2004). While Holfort and Albrecht (2007) speculate that the sudden freshening is due to a change in the source waters of DSOW, Hall et al. (2011) conclude however, from a systematic model analysis, that the salinity decrease is related to a wind driven increase in the volume transport in the overflow, so that more fresh bottom water enters the Irminger Sea, which takes more time to mix with the overlying saline NEADW to increase to standard salinities in the DSOW, DSOW $\mathrm{S}_{\mathrm{S}}$. So, the ultimate expla-

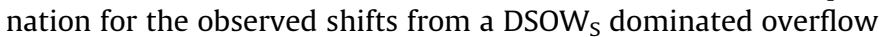
to overflow with DSOW $_{\mathrm{F}}$ characteristics and vice versa, although mediated by the wind forcing near Denmark Strait, still remains an open question.

In most papers on the hydrographic variability of the DSOW, much attention is given to the salinity, not to the temperature, although the observed variations in temperature have an effect on the density of the DSOW core, in magnitude about twice the effect of salinity variations. Macrander et al. (2005) found a temporary increase and following decrease of the DSOW temperature near the sill in Denmark Strait, from temperature sensors, mounted in ADCPs from 1999 to 2003. Temperature variation of DSOW further south was described by Dickson et al. (1999), based on data from temperature sensors in current meters that were deployed in an array off Angmagssalik. They reported changes in the temperature and thickness of the DSOW layer and upslope shifts of the DSOW core, interpreted as a response to the temperature in the eastern Fram Strait, three years earlier. The dominant time scale of these temperature variations was $\sim 5$ years. Similar changes of the DSOW temperature were observed one year later in the bottom layer in the Labrador Sea (Dickson et al., 2003). From the annual surveys of the AR7E section, we have found similar multi-year temperature variations with a 5 year time scale (Fig. 3a), although these temperature changes were considerably smaller in magnitude than those from the Angmagssalik array or Denmark Strait. Whether these multi-year temperature variations are determined by advected changes in the Norwegian Atlantic Current (Eldevik et al., 2009), the Spitsbergen Current in the eastern Fram Strait (Dickson et al., 1999), or by another cause, remains an open question.

A particular feature of the temperature variability, not reported before, is the significant annual cycle of the temperature in the DSOW core. A likely explanation is that the temperature cycle originates from Denmark Strait were the DSOW source waters are close to the surface, exposed to annual forcing by the atmosphere. In SST data the EGC front is also seen to move back and forth (east-west) across Denmark Strait annually. A rough estimate of the required advection time supports this explanation. However, such an annual cycle is not reported for continuous temperature records from Denmark Strait (Macrander et al., 2005) or for the temperature records from the Angmagssalik array at $\sim 63^{\circ} \mathrm{N}$ (Dickson et al., 1999). Another explanation may be an annual (wind-driven?) variation in the zonal position of the DSOW-core that draws the lateral gradient past the LOCO2 mooring, also causing an annual cycle in the temperature.

Summarizing we can state that the reported variations of DSOW hydrographic properties in the Irminger Sea may reflect variations of inflow of the DSOW across the sill in Denmark Strait (either amounts or properties), changing properties of entrained neighbouring water types, and shifts in the lateral distribution of the DSOW core in the Irminger Sea. The variations appear to occur on a wide range of time scales, from weekly to multi-decadal. The strongest changes were characteristic for the longest time scales, a situation which is characteristic for many geophysical time series which have a "reddish" spectrum. Despite explanations for the cause of these variations, put forward by different authors, a mechanistic picture for the causes (and effects!) is still missing. However "red" spectra, characteristic for integrative signals which are ultimately driven by random forcing (Hasselmann, 1976), can cause erroneous but apparently significant correlations (Wunsch, 1999).

\section{Acknowledgements}

The research leading to these results has received funding from the European Community's 7th framework programme (FP7/2007-2013) under grant agreement no. GA212643 (THOR: "Thermohaline Overturning-at Risk", 2008-2012) and from the Dutch "Climate for Spatial Planning" programme CS1. The moored instruments were acquired via the LOCO investment grant from the Netherlands Organisation for Scientific Research (NWO).

We thank the four reviewers who supplied us with many comments for the improvement of this paper. 


\section{References}

Alley, R.B., Marotzke, J., Nordhaus, W.D., Overpeck, J.T., Peteet, D.M., Pielke Jr., R.A Pierrehumbert, R.T., Rhines, P.B., Stocker, T.F., Talley, L...D., Wallace, J.M., 2003. Abrupt climate change. Science 299, 2005-2010.

Boessenkool, K.P., Hall, I.R., Elderfield, H., Yashayaev, I., 2007. North Atlantic climate and deep-ocean flow speed changes during the last 230 years. Geophys. Res. Lett. 34, L13614, http://dx.doi.org/10.1029/2007GL030285.

CLIVAR Scientific Steering Group, 1995. CLIVAR, A Study of Climate Variability and Predictability. Science Plan, WCRP-89. WMO/TD no. 690, Geneva. 157 pp.

De Jong, M.F., 2010. Hydrographic Variability of the Irminger Sea. Ph.D. Thesis, Utrecht University, pp. 208.

Dickson, B., Meincke, J., Vassie, I., Jungclaus, J., Østerhus, S., 1999. Possible predictability in overflows from the Denmark Strait. Nature 397, 243-246.

Dickson, B., Yashayaev, I., Meincke, J., Turrell, B.l, Dye, S., Holfort, J., 2002. Rapid freshening of the deep North Atlantic Ocean over the past four decades. Nature $416,832-837$.

Dickson, B., Dye, S.D., Jónsson, S., Köhl, A., Macrander, A., Marnela, M., Meincke, J., Olsen, S., Rudels, B., Valdimarsson, H., Voet, G., 2008. The overflow flux west of Iceland: variability, origins and forcing. In: Dickson, R.R., Meincke, J., Rhines, P. (Eds.), Arctic-Subarctic Ocean Fluxes. Springer Science+Bussines Media B.V., Dordrecht, The Netherlands, pp. 443-473.

Dickson, R.R., Brown, J., 1994. The production of North Atlantic deep water: sources, rates and pathways. J. Geophys. Res. C 99, 12319-12341.

Dickson, R.R., Curry, R., Yashayaev, I., 2003. Recent changes in the North Atlantic Phil. Trans. R. Soc. London A 361, 1917-1934.

Eldevik, T., Nilson, J.E.Ø., Iovino, D., Olsson, K.A., Sandø, A.B., Drange, H., 2009 Observed sources and variability of Nordic Seas Overflow. Nat. Geosci. 2, 406-410, http://dx.doi.org/10.1038/NGEO0518.

Hall, S., Dye, S.R., Heywood, K.J., Wadley, M.R., 2011. Wind forcing of salinity anomalies in the Denmark Strait overflow. Ocean Sci. 7, 821-834.

Hasselmann, K., 1976. stochastic climate models. Part I. Theory. Tellus 28, 473-485.

Holfort, J., Albrecht, T., 2007. Atmospheric forcing of salinity in the overflow of Denmark Strait. Ocean Sci. 3, 411-416.

Jonsson, S., Valdimarsson, H., 2004. A new path for the Denmark Strait overflow water from the Iceland Sea to Denmark Strait. Geophys. Res. Lett. 31, L03305 http://dx.doi.org/10.1029/2003GL019214.

Joyce, T., Corry, C., 1994. Requirements for WOCE Hydrographic Programme Data Reporting. WHPO Publication 90-1, Revision 2. 144 pp. Unpublished.

Macrander, A., Send, U., Valdimarsson, H., Jónsson, S., Käse, R.H., 2005. Interannual changes in the overflow from the Nordic Seas into the Atlantic Ocean through Denmark Strait. Geophys. Res. Lett. 32, L06606, http://dx.doi.org/10.1029/ 2004GL021463.

National Research Council (U.S.). Committee on Abrupt Climate Change, 2002. Abrupt Climate Change-Inevitable Surprises. National Academies Press, Washington, ISBN: 0-309-07434-7 230 pp.
Neumann, G., Pierson, W.J., 1966. Principles of Physical Oceanography. PrenticeHall Inc., Englewood Cliffs, N.J 545 pp.

Rudels, B., Fahrbach, E., Meincke, J., Budéus, G., Erikson, P., 2002. The East Greenland Current and its contribution to the Denmark Strait overflow. ICES J. Mar. Sci. 59, 1133-1154.

Sarafanov, A., 2009. On the effect of the North Atlantic oscillation on temperature and salinity of the subpolar North Atlantic intermediate and deep waters. ICES J. Mar. Sci. 66, 1448-1454, http://dx.doi.org/10.1093/icesjms/fsp094.

Sarafanov, A., Mercier, H., Falina, A., Sokov, A., Lherminier, P., 2010. Cessation and partial reversal of deep water freshening in the northern North Atlantic: observation-based estimates and attribution. Tellus 62A, 80-90.

Speer, K.G., McCartney, M.S., 1991. Tracing lower North Atlantic deep water across the equator. J. Geophys. Res. 96, 20,443-20,448.

Tanhua, T., Olsson, K.A., Jeansson, E., 2005. Formation of Denmark Strait overflow water and its hydro-chemical composition. J. Marine Syst. 57, 264-288.

Tchernia, P., 1980. Descriptive Physical Oceanography, Pergamon Press Ltd 253 pp.

Våge, K., Pickart, R.S., spall, M.A., Valdimarsson, H., Jónsson, S., Torres, D.J. Østerhus, S., Eldevik, T., 2011. Significant role of the North Icelandic Jet in th formation of Denmark Strait overflow water. Nat. Geosci. 4, 723-727, http://dx .doi.org/10.1038/NGEO1234.

van Aken, H.M., 2000. The hydrography of the mid-latitude northeast Atlantic Ocean: I: the deep water masses. Deep-Sea Res. I 47, 757-788.

van Aken, H.M., de Jong, M.F., Yashayaev, I., 2011. Decadal and multi-decadal variability of Labrador Sea water in the north-western North Atlantic Ocean derived from tracer distributions: heat budget, ventilation, and advection. Deep-Sea Res. I 58, 505-523.

van Sebille, E., Baringer, M.O., Johns, W.E., Meinen, C.S., Beal, L.M., de Jong, M.F., van Aken, H.M., 2011. Propagation pathways of classical Labrador Sea water from its source region to $26^{\circ} \mathrm{N}$. J. Geophys. Res. 116, C12027, http://dx.doi.org/ 10.1029/2011JC007171.

Wunsch, C., 1992. Decade-century changes in the ocean circulation. Oceanography 5, 99-106.

Wunsch, C., 1999. The interpretation of short climate records, with comments in the North Atlantic and Southern Oscillations. Bull. Am. Meteorol. Soc. 80, 245-255.

Yashayaev, I., 2007. Hydrographic changes in the Labrador Sea, 1960-2005. Prog. Oceanogr. 73, 242-276.

Yashayaev, I., Dickson, B., 2008. Transformation and fate of overflows in the northern North Atlantic. In: Dickson, R.R., Meincke, J., Rhines, P. (Eds.), ArcticSubarctic Ocean Fluxes. Springer Science+Business Media B.V., Dordrecht, The Netherlands, pp. 505-526.

Yashayaev, I., Bersch, M., van Aken, H.M., 2007. Spreading of the Labrador Sea Water to the Irminger and Iceland basins. Geophys Res Lett 34, L10602, http:// dx.doi.org/10.1029/2006gl028999. 